University of Nebraska - Lincoln

DigitalCommons@University of Nebraska - Lincoln

Drought Mitigation Center Faculty Publications Drought -- National Drought Mitigation Center

\title{
Assessing the Vegetation Condition Impacts of the 2011 Drought across the U.S. Southern Great Plains Using the Vegetation Drought Response Index (VegDRI)
}

Tsegaye Tadesse

Brian D. Wardlow

Jesslyn F. Brown

Mark D. Svoboda

Michael J. Hayes

See next page for additional authors

Follow this and additional works at: https://digitalcommons.unl.edu/droughtfacpub

Digitairt of the Climate Commons, Environmental Indicators and Impact Assessment Commons, Epmmpnental Monitoring Commons, Hydrology Commons, Other Earth Sciences Commons, and the Nettereresource Management Commons

Logo

This Article is brought to you for free and open access by the Drought -- National Drought Mitigation Center at DigitalCommons@University of Nebraska - Lincoln. It has been accepted for inclusion in Drought Mitigation Center Faculty Publications by an authorized administrator of DigitalCommons@University of Nebraska - Lincoln. 


\section{Authors}

Tsegaye Tadesse, Brian D. Wardlow, Jesslyn F. Brown, Mark D. Svoboda, Michael J. Hayes, Brian Fuchs, and Denise Gutzmer 


\title{
${ }^{2}$ Assessing the Vegetation Condition Impacts of the 2011 Drought across the U.S. Southern Great Plains Using the Vegetation Drought Response Index (VegDRI)
}

\author{
TSEgAYE TADESSE \\ National Drought Mitigation Center, School of Natural Resources, University of Nebraska-Lincoln, \\ Lincoln, Nebraska \\ BRIAN D. WARDLOW \\ Center for Advanced Land Management Information Technology, School of Natural Resources, \\ University of Nebraska-Lincoln, Lincoln, Nebraska \\ JESSLYN F. BROWN \\ U.S. Geological Survey, Earth Resources Observation and Science Center, Sioux Falls, South Dakota \\ Mark D. Svoboda, Michael J. Hayes, Brian Fuchs, and Denise Gutzmer \\ National Drought Mitigation Center, School of Natural Resources, University of Nebraska-Lincoln, \\ Lincoln, Nebraska
}

(Manuscript received 5 March 2014, in final form 4 September 2014)

\begin{abstract}
The vegetation drought response index (VegDRI), which combines traditional climate- and satellite-based approaches for assessing vegetation conditions, offers new insights into assessing the impacts of drought from local to regional scales. In 2011, the U.S. southern Great Plains, which includes Texas, Oklahoma, and New Mexico, was plagued by moderate to extreme drought that was intensified by an extended period of recordbreaking heat. The 2011 drought presented an ideal case study to evaluate the performance of VegDRI in characterizing developing drought conditions. Assessment of the spatiotemporal drought patterns represented in the VegDRI maps showed that the severity and patterns of the drought across the region corresponded well to the record warm temperatures and much-below-normal precipitation reported by the National Climatic Data Center and the sectoral drought impacts documented by the Drought Impact Reporter (DIR). VegDRI values and maps also showed the evolution of the drought signal before the Las Conchas Fire (the largest fire in New Mexico's history). Reports in the DIR indicated that the 2011 drought had major adverse impacts on most rangeland and pastures in Texas and Oklahoma, resulting in total direct losses of more than $\$ 12$ billion associated with crop, livestock, and timber production. These severe impacts on vegetation were depicted by the VegDRI at subcounty, state, and regional levels. This study indicates that the VegDRI maps can be used with traditional drought indicators and other in situ measures to help producers and government officials with various management decisions, such as justifying disaster assistance, assessing fire risk, and identifying locations to move livestock for grazing.
\end{abstract}

ఠ Denotes Open Access content.

Corresponding author address: Tsegaye Tadesse, National Drought Mitigation Center, School of Natural Resources, University of Nebraska-Lincoln, 816 Hardin Hall, 3310 Holdrege St. P.O. Box 830988, Lincoln, NE 68583-0988.

E-mail: ttadesse2@unl.edu

\section{Introduction}

In recent years, severe and extensive droughts in many parts of the world have resulted in food insecurity, loss of life, and negative economic impacts (Grigg 2014; Blunden and Arndt 2012). In the United States, these droughts have seriously affected agriculture, severely 
impacting crop and livestock sectors and significantly influencing food prices at the retail level (USDA-ERS 2013; Grigg 2014). Record heat waves and extreme drought have also been observed in the U.S. southern Great Plains (SGP). The 2011 drought over this region is a prime example, with the state of Texas experiencing its driest year since 1895 , when modern precipitation record keeping began (Combs 2012; Hoerling et al. 2013). The 2011 drought continued into 2012 and 2013 (Grigg 2014; Karl et al. 2012). According to the National Climatic Data Center (NCDC), the cost of the 2011 drought and excessive summer heat over the SGP is estimated at $\$ 12$ billion, with 95 human deaths reported (NCDC 2012). In Texas alone, agricultural losses due to heat and drought were estimated to be $\$ 7.6$ billion, which impacted global commodities like cotton and beef (Texas A\&M AgriLife 2012). In addition, from November 2010 through October 2011, Texas had a recordbreaking 23835 fires that burned more than 3.8 million acres and destroyed 2763 homes (Combs 2012). Thus, to reduce the impacts of drought at local, regional, and global levels, it is essential to assess and monitor the impacts with improved drought monitoring tools that could help decision makers develop more timely and efficient risk management strategies.

Traditionally, climate-based drought indices such as the Palmer drought severity index (PDSI) and standardized precipitation index (SPI) have been used for drought assessment and monitoring (McKee et al. 1993; Wells et al. 2004). However, these approaches have a limited spatial precision to map detailed drought patterns across the landscape because the indices are calculated from point-based meteorological measurements at discrete (weather station) locations that are often sparsely and nonuniformly distributed. As a result, traditional climate-based drought index maps often depict broadscale drought patterns that are produced from point-based data using statistical spatial interpolation techniques, and the level of spatial detail in those patterns is highly dependent on the density, geographic distribution, and data quality of the weather stations. In comparison, satellite remote sensing has proved useful for large-area vegetation monitoring given the synoptic coverage, high temporal repeat cycle, and continuous moderate spatial resolution of the spectral observations. In particular, satellite-derived time series normalized difference vegetation index (NDVI) data have been widely used for vegetation and ecosystem monitoring (Tucker et al. 1985; Jakubauskas et al. 2002; Singh et al. 2003; Maselli et al. 2003; Bayarjargal et al. 2006; Addink et al. 2007; Quiring and Srinivasan 2010). Analyses of time series NDVI data and NDVI-derived metrics have been effective means for identifying vegetation condition anomalies such as declines in vegetation health. Other vegetation indices (VIs) such as the vegetation condition index (Kogan 1990), which is based on a transformation of NDVI and thermal data acquired from satellites, have been produced for many years and are commonly used for national- to global-scale drought monitoring (Unganai and Kogan 1998; Bhuiyan et al. 2006; Alados et al. 2011). Although these VIs have proved valuable for monitoring general vegetation conditions, they are somewhat limited for effectively characterizing the impacts of drought on vegetation when used alone because the anomalies caused by drought stress cannot be discriminated from other environmental causes of vegetation stress (e.g., flooding, fire, disease, and pest infestation) and anthropogenic drivers (e.g., land-cover/land-use conversion) that produce similar droughtlike anomalies in these VIs. Additional information is typically required to discern the drought-impacted areas from locations where the vegetation is influenced by these other environmental and anthropogenic factors.

Hybrid indices integrating climatic and satellite data (e.g., the U.S. Drought Monitor) have also been developed to address the limitations of using traditional climate- and satellite-based indices to identify drought-specific impacts on vegetation conditions. One of these hybrid indices is the vegetation drought response index (VegDRI). The VegDRI is an operational tool for the continental United States (CONUS) that integrates satellite-based NDVI observations, climate-based drought index data, and several biophysical characteristics of the environment to produce an indicator that expresses the level of drought stress on vegetation (Wardlow et al. 2012; Tadesse et al. 2010; Brown et al. 2008). In this study, the VegDRI tool was used to assess the impacts of the recent drought across the SGP region to demonstrate its capability for the major 2011 drought event across this region. The Drought Impact Reporter (DIR), a tool developed by the National Drought Mitigation Center (NDMC), was used along with other data sources (e.g., NCDC) to evaluate the vegetation conditions across the SGP region depicted on VegDRI maps. The DIR is a comprehensive multisectoral database cataloging drought impacts. The specific objectives of this paper are (i) to assess the vegetation conditions in 2011 across the SGP using the VegDRI and (ii) to compare the VegDRI response to drought impacts over the SGP region collected by the NCDC and DIR related to vegetation condition, and to assess how well the index characterized these observed impacts for selected cases. 
Vegetation Drought Response Index Complete

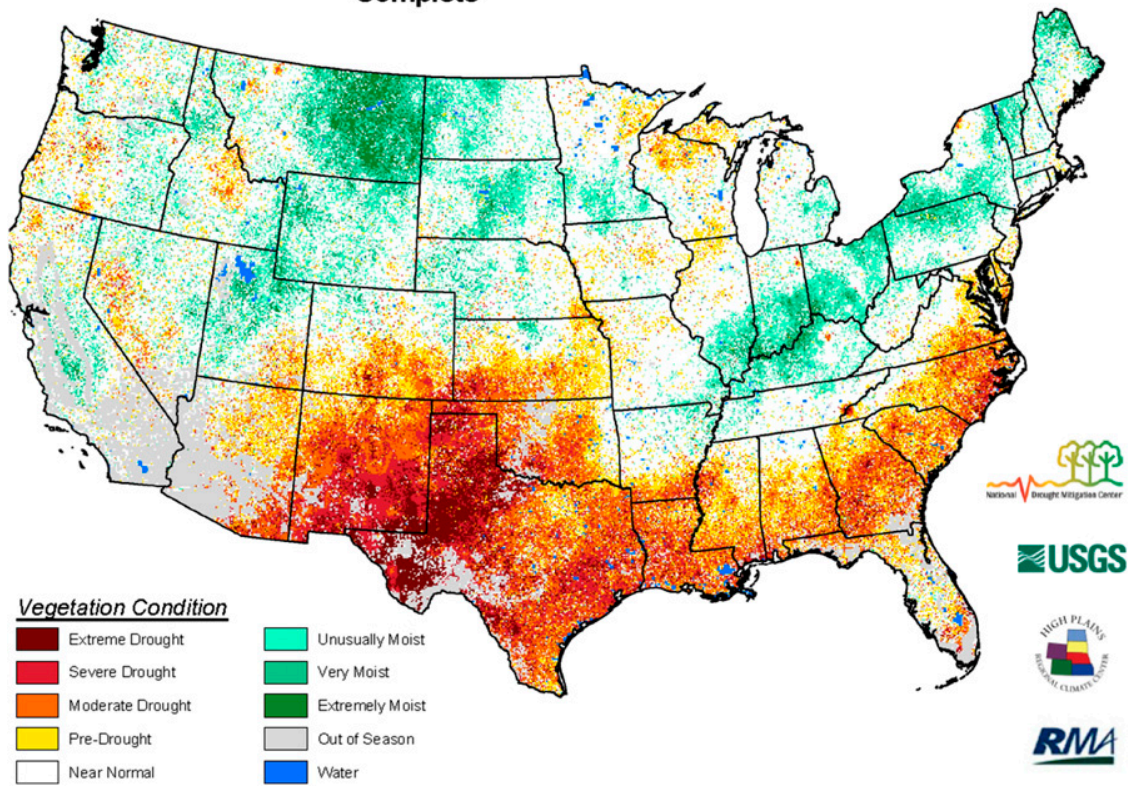

FIG. 1. Example of the VegDRI map for CONUS for 11 Jul 2011.

\section{Background/methods: VegDRI}

\section{a. VegDRI overview: Data inputs and methods}

VegDRI was developed to characterize the intensity and spatial pattern of drought-induced vegetation stress over the CONUS at a nominal spatial resolution of $1 \mathrm{~km}$ (Fig. 1). Satellite-based 1-km NDVI images provide a spatially continuous measure of general vegetation conditions, which are analyzed in combination with dryness information represented in the climate-based drought index data, to identify and characterize the intensity and spatial extent of drought conditions. Biophysical parameters such as land-cover type, soil available water holding capacity, percent of irrigated land, and ecological setting are also analyzed, as these characteristics can influence climate-vegetation interactions.

The VegDRI tool classifies four drought severity categories based on a modified version of the PDSI classification scheme (Palmer 1965). The VegDRI classes also contain four nondrought classes that reflect normal to moist conditions. In addition, the map includes two thematic classes that depict areas over which VegDRI values are not calculated. These classes include water and out of season (i.e., time when the vegetation is not photosynthetically active for a location as observed from satellite NDVI data). The data inputs used in VegDRI are described in the following sections.

\section{1) Climate-based DRought INDEX VARIABles}

Two climate-based drought indices, the SPI and the self-calibrated Palmer drought severity index (sc-PDSI), were incorporated into the VegDRI model. The SPI is designed to quantify the precipitation anomaly for a specific time period (e.g., previous 1, 3, 5, or 52 weeks) based on the long-term precipitation record over that same time period (McKee et al. 1993). The SPI is used as a measure of dryness in VegDRI, and a 36-week SPI was selected to represent seasonal precipitation patterns in the index (Tadesse et al. 2012; Wardlow et al. 2012). The sc-PDSI (Wells et al. 2004), which reflects how soil moisture conditions compare to normal conditions using a supply-and-demand model of a water balance equation, was also used as the dependent variable for the VegDRI. This index was an appropriate dependent variable for the VegDRI model in the United States (Brown et al. 2008) because the sc-PDSI accounts for the effects of precipitation and temperature, both of which strongly influence drought stress on vegetation. The VegDRI has adopted a modified version of the sc-PDSI drought severity classification scheme because it is a well-established way of communicating drought severity within the drought community.

\section{2) SATELLITE-BASED NDVI-RELATED VARIABLES}

Biweekly composited 1-km Advanced Very High Resolution Radiometer NDVI data from 1989 to 2008 
are used to calculate the percent average seasonal greenness (PASG) for input into VegDRI. PASG reflects how the vegetation conditions for a specific period during the growing season compare to historical average conditions for that same period over the historical record (Brown et al. 2008). An additional start-of-season anomaly (SOSA) metric was also calculated from the NDVI data to represent the departure of the start-ofseason (SOS) day of the year (DOY) from the historical median SOS DOY for each pixel that was included in the VegDRI to account for the different timings of emergence of various natural and agricultural vegetation types as well as land-cover change. Delays in the SOS by these various factors can result in lower-thannormal early season NDVI values that can mimic a drought signal when drought conditions do not exist. The SOSA also allows a key distinction to be made in VegDRI between areas with a low early season PASG due to environmental-related factors (e.g., drought or late-spring frost) versus nonenvironmental-related factors such as crop rotations or other land-cover changes that are unrelated to drought stress.

VegDRI as a measure of vegetation stress has a valid time envelope or "season." For model purposes, the season time limits were provided by data that estimated a typical SOS and end of the growing season (EOS) calculated from $20+$ years of remote sensing data rather than by an annually variable time envelope. This season is calculated for each pixel in the model and remains constant to provide standardization or temporal normalization to the seasonal greenness (SG) and to allow for more stable near-real-time monitoring. Therefore, VegDRI does not go "out of season" because of drought-related vegetation mortality. In that situation, VegDRI may indicate severe or extreme drought. Since the SG is an integration of time series NDVI data above a baseline (e.g., SOS NDVI threshold), the SG measure could be equal to zero if no NDVI value exceeds the baseline during the season. However, the SPI is also an input variable in VegDRI models, and if the SPI should rise significantly because of rainfall, the VegDRI also increases even if there is little or no increase in the SG. Recovering VegDRI (i.e., rising values after severe drought) may therefore be mainly linked to rising SPI because of rainfall increases. This is also dependent on many other variables in the models.

\section{3) STATIC BIOPHYSICAL VARIABLES}

Several static biophysical variables describing various environmental characteristics that influence drought stress on vegetation are also integrated into VegDRI, including the following. (i) Land use/land cover (LULC) is used to better parameterize the NDVI signals and climate-vegetation responses exhibited by different land-cover types in VegDRI. A 1-km LULC map was developed from the U.S. Geological Survey (USGS) 30-m National Land Cover Dataset (Homer et al. 2004).

(ii) Soil available water-holding capacity (SAWC) is used to represent the variability among soils to hold moisture and make it available to plants. Root zone available water holding capacity was extracted from the Soil Survey Geographic (SSURGO) database (USDA-NRCS 2013).

(iii) Ecoregion type, as represented by a 1-km ecoregion grid that was created from Omernik Level III ecoregion vector data (Omernik 1987), is used to divide the CONUS into a series of geographic regions with similar ecosystems and environmental resources defined using both abiotic and biotic criteria.

(iv) Elevation, in the form of a 1-km digital elevation grid extracted from the global 30-arc-s elevation dataset (GTOPO30) (Gesch et al. 1999), was included to distinguish elevation differences for a specific land cover and/or soil type, which can result in differing levels of sensitivity to drought stress among locations with similar land cover and/or soils.

(v) Percent of irrigated agriculture (Per_irrig) differentiates irrigated areas with targeted water applications from rain-fed agricultural areas to represent the range of crop susceptibility (from very low to high) to drought stress. A $1-\mathrm{km}$ map depicting the spatial distribution of irrigated agriculture was generated from a 250-m Moderate Resolution Imaging Spectroradiometer (MODIS) Irrigated Agriculture Dataset (MIrAD) developed from a combination of MODIS NDVI data, U.S. Department of Agriculture (USDA) county irrigation statistics, and LULC information (Pervez and Brown 2010).

In developing the VegDRI model, each input variable was processed, summarized, and organized into a database. Figure 2 shows the VegDRI methodology, which includes six steps: 1) point data are extracted from gridded data input variables (e.g., PASG, LULC, and soils) and combined with tabular historical climate data in the database for each weather station location; 2) empirically derived VegDRI models are developed for each biweekly period over the calendar year by applying a classification and regression tree (CART) analysis technique to the historical information in the database; 3) gridded images are generated for near-real-time data input variables; 4) the biweekly VegDRI models are 


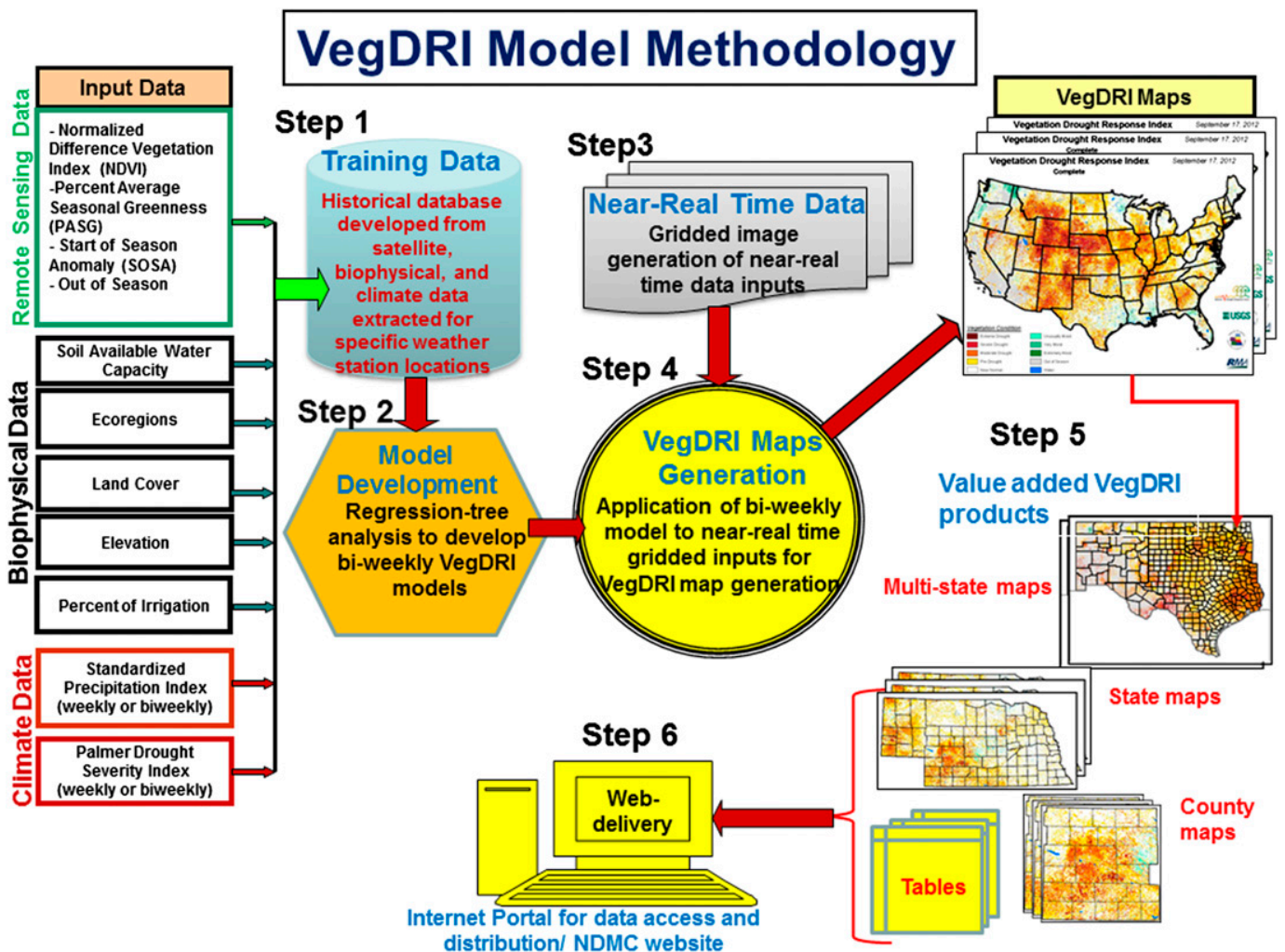

FIG. 2. The VegDRI methodology: model inputs, process, development, and dissemination of the VegDRI products.

applied to geospatial data to produce a near-real-time VegDRI map; 5) value-added VegDRI products are created, such as customized multistate maps, state maps, county maps, and important highlights (text and tables); and 6) these products are disseminated to the general public in various ways, including Internet portals for data access and distribution (e.g., NDMC website: http:// drought.unl.edu/).

\section{b. VegDRI database development, model generation, and implementation}

To develop the VegDRI model, a database of satellite, climate, and biophysical data was assembled for selected locations over the CONUS with long historical weather station records and minimal missing data. Biweekly historical SPI and self-calibrated PDSI data were calculated and sequentially ordered for each station. For the variables that are in a gridded format (e.g., LULC), summary statistics were calculated for a $3 \times 3 \mathrm{~km}^{2}$ pixel window centered on each station (point) location. Average values for continuous variables (e.g., elevation) and the dominant (or majority) class for the categorical variables (e.g., majority land-cover type) were calculated from within the window and added to the database for each station. Biweekly historical PASG values were stacked in the same manner as the climate data, and a single SOSA value per year was used for each station. A single constant value was used for each of the static biophysical records (e.g., SAWC) across the historical (time series) record in the database. The extracted records for each station were organized in the database to be used in developing the VegDRI models for each biweekly period.

A commercial CART algorithm, Cubist (Rulequest 2013), was used to analyze the historical data and generate biweekly, rule-based piecewise linear regressiontree models. This CART algorithm performs a binary recursive partitioning process that splits the initial set of training observations (root or parent node) into two child nodes that contain a subset of more homogeneous training observations. This process is repeated, further subdividing the training data into pairs of child nodes until the partitioning process is terminated by userdefined criteria (e.g., minimum rule cover or percent of cases allowed to generate a rule; Breiman et al. 1984; Yang et al. 2003). The CART algorithm produces a series of rule-based models from this partitioning. Each rule set has a corresponding multivariate linear regression equation that can be used to produce the values of the VegDRI. The VegDRI models are composed of an unordered set of rules, with each rule having the 

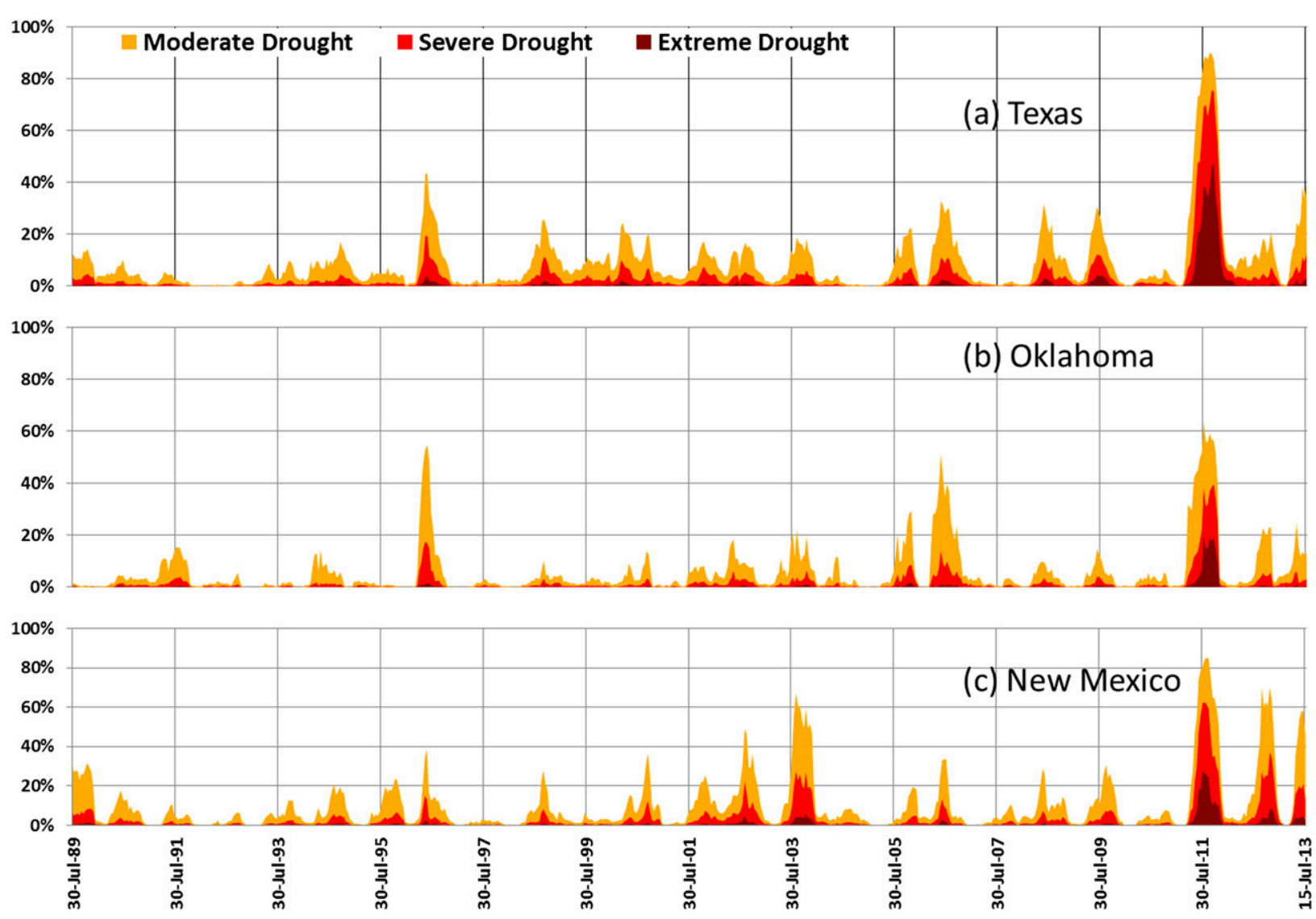

FIG. 3. Percent area of historical drought in (a) Texas, (b) Oklahoma, and (c) New Mexico based on VegDRI: from July 1989 through July 2013.

syntax: if $\mathrm{x}$ conditions are met, then use the associated linear regression model. An example of the rules generated by the Cubist algorithm for VegDRI is given below.

\section{Example rule 1:}

if: Ecoregion in \{western Corn Belt plains, central Great Plains\}, LULC in \{grassland, pasture/hay, row crops $\}$, SPI $<-1.5$, and Elevation $>300 \mathrm{~m}$, then: VegDRI $=1.2+0.06 \mathrm{PASG}-0.7 \mathrm{SAWC}+$ 0.01Elevation -0.04 Per_irrig.

If two or more rules in the Cubist model apply to the case, then the VegDRI model values from each regression equation will be averaged to arrive at the final VegDRI value. The rule sets from the appropriate biweekly Cubist model were then applied to the gridded image input data using MapCubist software, developed at the USGS Earth Resources Observation and Science (EROS) Center, to produce the VegDRI (Brown et al. 2008). The climate-based indices and the NDVI-derived metrics for each biweekly period and the corresponding biweekly model were applied to this information along with the static biophysical variables to generate the VegDRI map in near-real time. Since point-based near-real-time SPI data are used to provide a $1-\mathrm{km}$ resolution grid (using the inverse distance weight method), the grid's spatial accuracy depends on the number of stations available at the time and the topography of the area. Thus, the VegDRI resolution would have limited spatial precession because of the climate data input.

\section{The 2011 drought assessment across the SGP}

a. VegDRI-based vegetation condition assessment of historical drought across the SGP

VegDRI maps are produced every two weeks and provide regional- to subcounty-scale information about drought's effects on vegetation across the continental United States. For this vegetation condition assessment, spatiotemporal VegDRI data for the SGP states (i.e., Oklahoma, New Mexico, and Texas) were extracted from the CONUS VegDRI model products for the 2011 study year. Figures $3 a-c$ show the percent area in drought (by drought severity category) in Texas, Oklahoma, and New Mexico based on VegDRI historical records from 1989 to 2013. 
TABLE 1. Summary of statewide 3-month average temperature and total precipitation at a monthly time step from April to October 2011 for Texas.

\begin{tabular}{|c|c|c|c|c|c|c|c|c|}
\hline \multicolumn{5}{|c|}{ Temperature } & \multicolumn{4}{|c|}{ Precipitation } \\
\hline Period & $\begin{array}{l}\text { 3-month } \\
\text { avg }\left({ }^{\circ} \mathrm{C}\right)\end{array}$ & $\begin{array}{c}\text { Long-term } \\
\text { avg (normal) } \\
\left({ }^{\circ} \mathrm{C}\right)\end{array}$ & $\begin{array}{c}\text { Departure } \\
\text { from } \\
\text { normal }\left({ }^{\circ} \mathrm{C}\right)\end{array}$ & $\begin{array}{c}\text { Rank } \\
\text { (of } 119 \mathrm{yr} \text { ) }\end{array}$ & $\begin{array}{c}\text { 3-month } \\
\text { total } \\
(\mathrm{mm})\end{array}$ & $\begin{array}{l}\text { Long-term } \\
\text { avg (normal) } \\
(\mathrm{mm})\end{array}$ & $\begin{array}{c}\text { Departure } \\
\text { from normal } \\
\quad(\mathrm{mm})\end{array}$ & $\begin{array}{c}\text { Rank } \\
\text { (of } 119 \mathrm{yr} \text { ) }\end{array}$ \\
\hline Feb-Apr 2011 & 15.7 & 14.2 & +1.5 & 15 th warmest & 45.72 & 149.35 & -103.63 & First driest \\
\hline Mar-May 2011 & 20.3 & 18.3 & +2.0 & Third warmest & 67.56 & 195.58 & -128.02 & First driest \\
\hline Apr-Jun 2011 & 24.6 & 22.4 & +2.2 & First warmest & 86.36 & 226.06 & -139.70 & Second driest \\
\hline May-Jul 2011 & 27.7 & 25.7 & +2.0 & Second warmest & 85.34 & 223.01 & -137.67 & Second driest \\
\hline Jun-Aug 2011 & 30.4 & 27.4 & +3.0 & First warmest & 62.99 & 192.79 & -129.80 & First driest \\
\hline Jul-Sep 2011 & 29.1 & 26.7 & +2.4 & First warmest & 66.55 & 193.29 & -126.74 & Second driest \\
\hline Aug-Oct 2011 & 25.3 & 23.8 & +1.5 & First warmest & 104.14 & 200.91 & -96.77 & Sixth driest \\
\hline
\end{tabular}

As Figs. 3a-c show, based on the 25-yr historical records, the SGP experienced the largest areal extent of drought in 2011 in all drought categories (i.e., moderate, severe, and extreme). Thus, the 2011 drought, which was one of the worst droughts in recent years (and on record for the region given the multiyear nature of the drought), has been assessed in more detail in the following section.

\section{b. Drought assessment of the 2011 growing season (April-October) across the SGP based on the NCDC's historical records}

The following climatic data and statistics (Tables 1-3) summarize the 2011 drought during the SGP growing season (April-October) based on the NCDC's historical records from 1895 to 2013 (NCDC 2013).

Tables 1-3 show the statewide temperature and precipitation records that were observed in the 2011 growing season (April-October) for the 3-month periods moving at a monthly time step for Texas, Oklahoma, and New Mexico. The first column shows the 3-month period. For example, February-April 2011 shows the 3-month period that ends April 2011. Similarly, statewide 3-month data are summarized at the end of each month from May to October, showing the climatic records throughout the growing season at a monthly time step. The columns to the right of each period show (i) the temperature summary (including the 3-month temperature average observed in 2011), the historical average temperature for the same 3-month period (normal), the average temperature departure in degrees Celsius from normal for the same period [i.e., negative values are below normal and positive values are above normal (long-term mean)], and the ranking of the temperature value in 2011 among the 119 years; and (ii) the precipitation summary, including the 3-month statewide total precipitation, the historical precipitation normal for the same 3-month period, the departure of total precipitation (in millimeters) for the same period [i.e., negative values are below normal and positive values are above normal (long-term mean)], and the ranking of the total amount of 3-month statewide precipitation among the 119 years of record.

Generally, Tables 1-3 show that the SGP experienced record warm temperatures and much-below-normal precipitation. All three states (Texas, Oklahoma, and New Mexico) had top rankings in 2011 in terms of warmest and driest seasons of the 119 years of historical records. The record high temperatures and low precipitation across the SGP region in 2011 had significant impacts on vegetation condition, as discussed for VegDRI in the following section.

TABLE 2. As in Table 1, but for Oklahoma.

\begin{tabular}{|c|c|c|c|c|c|c|c|c|}
\hline \multicolumn{5}{|c|}{ Temperature } & \multicolumn{4}{|c|}{ Precipitation } \\
\hline Period & $\begin{array}{l}\text { 3-month } \\
\operatorname{avg}\left({ }^{\circ} \mathrm{C}\right)\end{array}$ & $\begin{array}{c}\text { Long-term } \\
\text { avg (normal) } \\
\left({ }^{\circ} \mathrm{C}\right)\end{array}$ & $\begin{array}{l}\text { Departure } \\
\text { from normal } \\
\qquad\left({ }^{\circ} \mathrm{C}\right)\end{array}$ & $\begin{array}{c}\text { Rank } \\
\text { (of } 119 \mathrm{yr} \text { ) }\end{array}$ & $\begin{array}{c}\text { 3-month } \\
\text { total } \\
(\mathrm{mm})\end{array}$ & $\begin{array}{l}\text { Long-term } \\
\text { avg (normal) } \\
(\mathrm{mm})\end{array}$ & $\begin{array}{l}\text { Departure } \\
\text { from normal } \\
\qquad(\mathrm{mm})\end{array}$ & $\begin{array}{c}\text { Rank } \\
\text { (of } 119 \mathrm{yr} \text { ) }\end{array}$ \\
\hline Feb-Apr 2011 & 10.7 & 9.8 & +0.9 & 29 th warmest & 139.7 & 191.01 & -51.31 & 24th driest \\
\hline Mar-May 2011 & 16.0 & 14.8 & +1.2 & 18 th warmest & 205.99 & 273.81 & -67.82 & 23rd driest \\
\hline Apr-Jun 2011 & 21.8 & 19.9 & +1.9 & Fourth warmest & 216.66 & 313.44 & -96.78 & 16th driest \\
\hline May-Jul 2011 & 26.8 & 24.1 & +2.7 & First warmest & 150.11 & 299.47 & -149.36 & Third driest \\
\hline Jun-Aug 2011 & 30.5 & 26.5 & +4.0 & First warmest & 105.41 & 247.14 & -141.73 & Third driest \\
\hline Jul-Sep 2011 & 28.2 & 25.8 & +2.4 & Fourth warmest & 115.32 & 231.14 & -115.82 & Sixth driest \\
\hline Aug-Oct 2011 & 23.1 & 22.1 & +1 & 17 th warmest & 169.67 & 236.22 & -66.55 & 27 th driest \\
\hline
\end{tabular}


TABLE 3. As in Table 1, but for New Mexico.

\begin{tabular}{|c|c|c|c|c|c|c|c|c|}
\hline \multicolumn{5}{|c|}{ Temperature } & \multicolumn{4}{|c|}{ Precipitation } \\
\hline Period & $\begin{array}{l}\text { 3-month } \\
\text { avg }\left({ }^{\circ} \mathrm{C}\right)\end{array}$ & $\begin{array}{c}\text { Long-term } \\
\text { avg (normal) } \\
\left({ }^{\circ} \mathrm{C}\right)\end{array}$ & $\begin{array}{l}\text { Departure } \\
\text { from normal } \\
\quad\left({ }^{\circ} \mathrm{C}\right)\end{array}$ & $\begin{array}{c}\text { Rank } \\
\text { (of } 119 \mathrm{yr} \text { ) }\end{array}$ & $\begin{array}{l}\text { 3-month } \\
\text { total } \\
(\mathrm{mm})\end{array}$ & $\begin{array}{l}\text { Long-term } \\
\text { avg (normal) } \\
(\mathrm{mm})\end{array}$ & $\begin{array}{l}\text { Departure } \\
\text { from normal } \\
\quad(\mathrm{mm})\end{array}$ & $\begin{array}{c}\text { Rank } \\
\text { (of } 119 \mathrm{yr} \text { ) }\end{array}$ \\
\hline Feb-Apr 2011 & 8.2 & 7.0 & +1.2 & 16th warmest & 20.57 & 49.53 & -28.96 & Eighth driest \\
\hline Mar-May 2011 & 12.7 & 11.1 & +1.6 & Eighth warmest & 18.03 & 60.45 & -42.42 & Fourth driest \\
\hline Apr-Jun 2011 & 17.1 & 15.8 & +1.3 & 14th warmest & 18.54 & 72.14 & -53.60 & First driest \\
\hline May-Jul 2011 & 20.9 & 19.8 & +1.1 & 13 th warmest & 47.24 & 115.82 & -68.58 & First driest \\
\hline Jun-Aug 2011 & 24.1 & 21.8 & +2.3 & First warmest & 85.60 & 151.13 & -65.53 & Second driest \\
\hline Jul-Sep 2011 & 22.9 & 21.0 & +1.9 & First warmest & 119.63 & 162.05 & -42.42 & 14th driest \\
\hline Aug-Oct 2011 & 18.9 & 17.5 & +1.4 & Third warmest & 111.51 & 130.05 & -18.54 & 40th driest \\
\hline
\end{tabular}

\section{c. VegDRI-based vegetation condition assessment of the 2011 drought across the SGP}

Because this study is focused mainly on vegetation condition assessment, the VegDRI data were extracted for the primary growing season (between April and October) in 2011. Figure 4 shows the seasonal time series of the VegDRI for Texas, Oklahoma, and New Mexico at a biweekly time step. The monthly assessments for each state are briefly summarized below.

\section{1) APRIL}

Early in the 2011 growing season, conditions were drier than normal across the region, as shown by extensive predrought and moderate drought coverage in VegDRI (Figs. 4a,b). The early season drought conditions continued to intensify across the region as the spring thunderstorm season largely failed to materialize. According to NCDC (Table 1), the statewide 3-month total precipitation value for Texas was the lowest in its $119-\mathrm{yr}$ period of record. Similarly, Oklahoma and New Mexico had the 24th and eighth driest 3-month period, respectively, of their 119-yr historical records (Tables 2 and 3). In Texas, the VegDRI map shows $15.5 \%$ and $21.3 \%$ of the state in the moderate to extreme drought categories on 9 and 23 April, respectively (Figs. 4a,b). In Oklahoma, most areas had below-normal precipitation (i.e., the 3-month total statewide precipitation was $51 \mathrm{~mm}$ below average) with above-normal temperatures (about $1^{\circ} \mathrm{C}$ above long-term mean) during the period from February to April (Table 2). Based on VegDRI, moderate to extreme drought affected about $27.5 \%$ of Oklahoma on 9 April and expanded to $29.6 \%$ by 23 April (Figs. 4a,b). In New Mexico, the VegDRI map shows (Fig. 4a) about $1 \%$ of the state's area was classified in moderate to extreme drought conditions on 9 April. However, most areas of the state (91\%) were out of the growing season at the beginning of April, so the percent area in drought was much lower than surrounding states, with large areas considered inseason in April. The drought further intensified on 23 April, covering about $8.6 \%$ of the state, whereas the areas out of growing season covered $33.7 \%$ of the state in mid-April (Figs. 4a,b).

\section{2) MAY}

The drought condition worsened across the majority of the SGP during this month (Tables 1-3). In Texas, widespread drought intensification continued as the spring thunderstorm season again largely failed. The statewide 3-month precipitation for Texas was the driest (only $67.6 \mathrm{~mm}$ ) on record for the same period (Table 1). The VegDRI map shows $29.1 \%$ of Texas in moderate to extreme drought on 2 May, with expanded geographic coverage of these drought severities to levels of $42.1 \%$ and $52.9 \%$ on 21 May and 4 June, respectively (Figs. 4c,d,b). In Oklahoma, severe weather events occurred during the month over central and eastern parts of the state (NWS 2011c). This reduced the area of the drought on the VegDRI map to $28.6 \%$ in early May (Fig. 4c). However, because of the long-term precipitation deficits and below-normal rainfall in May (the statewide 3-month precipitation total was only $206 \mathrm{~mm}$, which was $68 \mathrm{~mm}$ less than the mean), the area of moderate to extreme drought in Oklahoma quickly rebounded to $40.7 \%$ and $42.2 \%$ by 21 May and 4 June, respectively (Figs. 4d,e). In New Mexico, more than half of the state was in season in May. Northwestern New Mexico averaged $74 \%$ of normal precipitation, while southern New Mexico was the driest region at 5\% of normal precipitation. According to NCDC, New Mexico's statewide precipitation for spring (MarchMay) was only $18 \mathrm{~mm}$ (42 mm below normal and the 8 th driest of 119 years). Because of this precipitation deficit, about $33.1 \%$ of the state was under moderate to extreme drought on 2 May (Fig. 4c) according to VegDRI, expanding to about $50 \%$ of the state at the end of the month (Figs. 4d,e). 


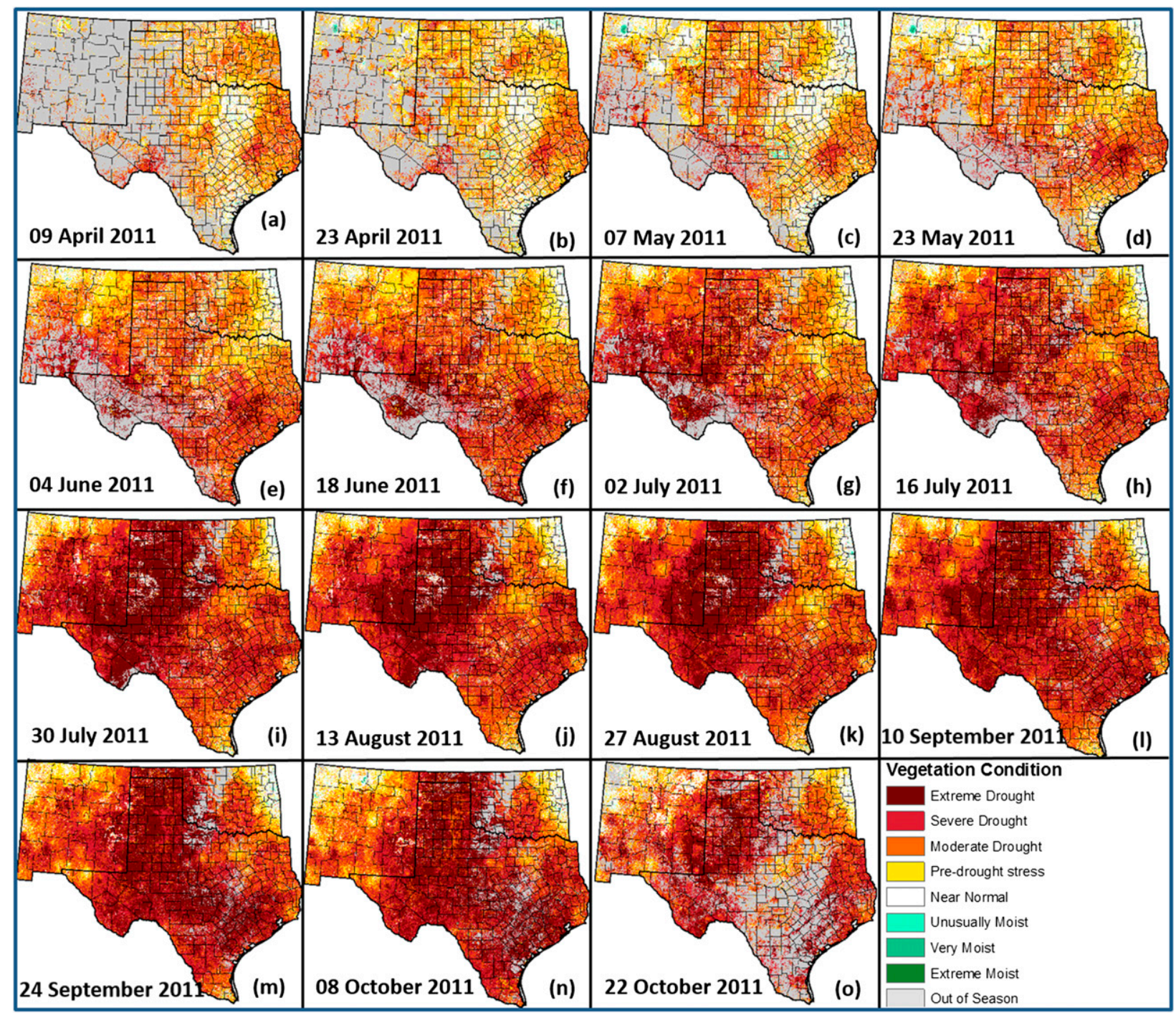

FIG. 4. The seasonal time series VegDRI maps of the SGP for (a) 9 Apr, (b) 23 Apr, (c) 7 May, (d) 21 May, (e) 4 Jun, (f) 18 Jun, (g) 2 Jul, (h) $16 \mathrm{Jul}$, (i) $30 \mathrm{Jul}$, (j) 13 Aug, (k) 27 Aug, (l) $10 \mathrm{Sep}$, (m) 24 Sep, (n) 8 Oct, and (o) 22 Oct 2011.

\section{3) JUNE}

The drought further intensified across the SGP. In Texas, vegetation conditions continued to steadily decline as precipitation was sporadic and infrequent. Because of the drier-than-normal conditions (statewide 3 -month precipitation from April to June was $139 \mathrm{~mm}$ below normal), about $64 \%$ of Texas on the VegDRI map was under moderate to extreme drought in June. In Oklahoma, moderate to extreme drought conditions continued to expand across the state. The 3-month (April-June) statewide precipitation was $217 \mathrm{~mm}$ (97 mm below normal). The VegDRI maps showed about $42 \%$ of the state under these conditions on 18 June. In New Mexico, precipitation in June was far below normal. Only a few spots in the eastern plains of New Mexico received up to $60 \%$ of normal precipitation, while many areas in the northwest part of the state reported no measurable rainfall during the month. Table 3 shows that the statewide 3-month (April-June) precipitation for New Mexico was the driest on record (54 $\mathrm{mm}$ less than the mean). This significant precipitation deficit is reflected in the VegDRI maps, with the spatial extent of moderate to extreme drought conditions expanding to more than $70 \%$ of the state by the end of June.

4) JULY

The SGP was already in the midst of an exceptionally hot and dry summer, causing significant impacts on 
vegetation. In Texas, the 3-month (May-July) statewide average temperature was $+2^{\circ} \mathrm{C}$ hotter than normal for the same period and the second driest $(138 \mathrm{~mm}$ below normal) among 119 years. Dry conditions continued into the summer across the state as June ranked as the driest month ever in many places [e.g., Lubbock, where no measureable rainfall was observed in June (NWS 2011b)]. The VegDRI maps captured and depicted these prolonged unusually dry and hot conditions with $73.5 \%$ and $78.4 \%$ of the state under moderate to extreme drought on 16 and 30 July, respectively. This was the peak areal extent of moderate to extreme drought for the 2011 growing season, and it continued in August. In Oklahoma, the hotter- and drier-than-normal conditions continued throughout most of Oklahoma during July. Table 2 shows that the statewide 3-month temperature for Oklahoma was the warmest $\left(+2.7^{\circ} \mathrm{C}\right.$ above normal) and the statewide 3-month precipitation was the third driest ( $149 \mathrm{~mm}$ less than the mean observed) on record. The VegDRI maps reflected these conditions with an expansion of moderate to extreme drought designation increasing to $46.5 \%$ and $56.4 \%$ of the state on 16 and 30 July, respectively. In New Mexico, much of south-central and southwest New Mexico saw significant rainfall [e.g., Albuquerque had $10 \mathrm{~mm}$ (0.4 in.)] during July from spotty monsoonal showers and thunderstorms, their first significant precipitation events since the start of 2011 (NWS 2011a). Even though the state showed some improvement, because of a long-term precipitation deficit (e.g., statewide 3-month precipitation total from May to July was $65 \mathrm{~mm}$ less than the mean), the VegDRI maps showed significant areas $(90 \%-93 \%)$ of New Mexico under moderate to extreme drought conditions as the vegetation did not recover from the severe stress during this short period of time.

\section{5) August}

Widely scattered thunderstorms occurred over parts of the SGP in August, resulting in a slight improvement in drought conditions in the region. In Texas, scattered storms were observed over most parts of the state in August. However, this did little to improve drought impacts on vegetation because the 3-month (JuneAugust) total statewide average precipitation was $63 \mathrm{~mm}$ (130 $\mathrm{mm}$ below average), and the 3 -month average temperature was the warmest on record $\left(+3^{\circ} \mathrm{C}\right.$ above long-term mean) for the same period. Thus, the VegDRI maps showed $76.7 \%$ and $71.6 \%$ of the state under moderate to extreme drought conditions on 13 and 27 August, respectively. In Oklahoma, some changes were observed in the form of relatively cooler temperatures and increased rainfall over most of the state. Nevertheless, because of hotter and drier conditions throughout the summer as a whole, significant areas of Oklahoma did not recover and remained under moderate to extreme drought. As shown in Table 2, the 3-month statewide precipitation from June to August was the third driest (141 $\mathrm{mm}$ below average) and the 3-month average temperature was the warmest $\left(+4^{\circ} \mathrm{C}\right.$ above long-term mean) on record. The VegDRI maps showed $48.7 \%$ and $47.8 \%$ of the state under moderate to extreme drought on 13 and 27 August, respectively. In New Mexico, rainfall was observed over many locations, but not the far southeastern counties (NWS 2011a). Even so, the effects of the hotter and drier conditions throughout the summer persisted for New Mexico. As shown in Table 3, the 3-month (JuneAugust) total statewide precipitation for New Mexico was $65 \mathrm{~mm}$ below average (the second driest among 119 years) and the statewide temperature was $+2.3^{\circ} \mathrm{C}$ above average (the warmest on record). This was reflected on the VegDRI maps, which showed that about $94 \%$ of the state was under moderate to extreme drought from midto late August.

\section{6) SEPTEMBer}

Widespread rainfall and lower temperatures occurred over the SGP, bringing improvement to drought conditions across the region. However, extended drought conditions had already taken their toll on vegetation, resulting in only slight improvement of the drought conditions on the VegDRI maps (Figs. 4l,m). In Texas, storms brought much-needed rain and relief from the intense heat that was observed throughout the season. Even so, the statewide 3-month (July-September) precipitation total was $126 \mathrm{~mm}$ less than the average (the second driest on record) and $+2.4^{\circ} \mathrm{C}$ hotter than the 119-yr average temperature for the same period. Thus, because of the long-term rainfall deficit, $65 \%-70 \%$ of Texas remained in moderate to extreme drought. In Oklahoma, even though the rain helped to improve the drought, the VegDRI maps show that $47 \%-50 \%$ of the state was still in moderate to extreme drought. This was in agreement with the statewide 3-month (JulySeptember) precipitation deficit by about $116 \mathrm{~mm}$ (the sixth driest). In New Mexico, according to the National Weather Service, the northwest plateau climate division averaged a statewide-best $89 \%$ of normal precipitation, while the southeastern plains climate division was the driest region at $34 \%$ of normal (NWS 2011a). Generally, according to the NCDC (2013), the statewide average data for New Mexico show a 42-mm precipitation deficit from the long-term average for the 3-month (JulySeptember) period. In addition, this 3-month period (July-September) was the warmest $\left(+1.9^{\circ} \mathrm{C}\right.$ above average) on record for the same period. Thus, because of 
the record warm conditions and long-term rainfall deficit throughout summer, the VegDRI maps still showed about $90 \%-93 \%$ of areas in New Mexico in moderate to extreme drought.

\section{7) OCtOBeR}

Heavy showers and thunderstorms visited the SGP in October, bringing more rains to parts of the region. In Texas, heavy rain fell across the southeast Texas Panhandle and eastern rolling plains in October. However, according to NCDC, the statewide average precipitation for Texas was $56.13 \mathrm{~mm}$ in October, which was still $11 \mathrm{~mm}(16 \%)$ below the long-term mean (NCDC 2013). Also, the 3-month (August-October) statewide total was about $104 \mathrm{~mm}$, which was $97 \mathrm{~mm}(48 \%)$ less than normal (Table 1). Because of this seasonal precipitation deficit, $68.8 \%$ of the state was under moderate to extreme drought. In Oklahoma, October marked the return of beneficial rainfall for the state. NCDC reported $72.4 \mathrm{~mm}$ statewide average precipitation in October (1 month), which was close to normal (77.2 mm) (NCDC 2013). Nonetheless, the 3-month (August-October) statewide precipitation for Oklahoma was $169.7 \mathrm{~mm}$, which was $66.6 \mathrm{~mm}(28 \%)$ less than the normal for the same period (Table 2). Thus, because of this long-term precipitation deficit, the VegDRI showed that $46 \%$ of the state was under moderate to extreme drought. In New Mexico, through October, the northwest plateau climate division averaged a statewide-best $96 \%$ of normal precipitation, while the southeastern plains climate division was the driest region at $38 \%$ of normal precipitation. According to NCDC (2013), the 3-month (August-October) statewide precipitation for New Mexico was $111.5 \mathrm{~mm}$, which was $130 \mathrm{~mm}$ (54\%) less than the mean. The VegDRI map showed about $89 \%$ of the state under moderate to extreme drought. This indicates that no significant recovery was observed, since it was too late in the year for vegetation regrowth.

\section{8) STATISTICAL SUMMARY OF AREAL COVERAGE OF DROUGHT IN 2011 OVER THE SGP USING VEGDRI}

Table 4 shows the statistical summary of spatial coverage of drought in Texas, Oklahoma, and New Mexico based on the VegDRI drought classification. During the 2011 growing season (from April to October), the total percent area under drought in Texas ranged from $15.5 \%$ to $78.4 \%$. The percent area of Oklahoma and New Mexico under drought conditions ranged from $27.5 \%$ to $56.4 \%$ and from $0.6 \%$ to $94.1 \%$, respectively, during the 2011 growing season (Table 4). The percent area of moderate to severe drought across the region showed how widespread and severe the conditions were for vegetation growth.

\section{d. Drought impacts assessment}

\section{1) The Drought IMPACt Reporter}

In 2005, the NDMC developed the DIR, the first multisectoral database cataloging drought impacts for the United States (http://droughtreporter.unl.edu/). Much of the information contained in the DIR comes from media reports, with a smaller percentage coming from government agency reports, individual user reports, and the Community Collaborative Rain, Hail and Snow (CoCoRaHS) weather observer network. In this study, we have used this comprehensive data source to generate, analyze, and compile drought impacts information for the SGP region. The DIR classifies drought impacts into nine sectoral categories: agriculture, fire, plants and wildlife, business and industry, energy, society and public health, tourism and recreation, water supply and quality, and general awareness. Because the VegDRI is designed to identify drought effects on the general vegetation condition, this study was mainly focused on the agricultural sector. However, other direct and indirect impacts (e.g., livestock and wildfire) are also considered to a lesser extent to better show the overall impacts.

\section{2) OVERVIEW OF THE 2011 DROUGHT BASED ON THE DIR}

During the growing season across the SGP region, drought conditions deteriorated rapidly, impacting every aspect of daily life from farmers and ranchers struggling to keep crops and livestock alive to communities striving to conserve water to ensure an adequate supply for basic needs and firefighting (Grigg 2014). The reports collected by the NDMC's DIR show that crops withered, pasture and grazing lands dried up, water supplies dwindled, wildlife populations shrank, trees died, and dust storms reduced visibility. The estimated agricultural losses (including livestock, cotton, corn, wheat, and sorghum) in 2011 amounted to $\$ 7.6$ billion in Texas (Texas A\&M AgriLife 2012) and at least $\$ 2$ billion in Oklahoma (NWS 2011c). In addition, more than 300 million trees died in Texas, while Christmas tree growers in Oklahoma reported that thousands of trees died from the drought and heat (TreeGeek 2012). Dying trees were also reported by observers in eastern and southeastern New Mexico during this 2011 growing season (Bryan 2011).

The seasonal time series VegDRI maps of the SGP (Fig. 4) show that the 2011 drought had significant impacts on the rangelands of the SGP that resulted in severe impacts on the economy. According to a USDA 
TABLE 4. Percent area of Texas, Oklahoma, and New Mexico under moderate to extreme drought conditions in 2011 using VegDRI. These values do not include the drier-than-normal condition that is classified as "predrought" in the VegDRI drought categories. The "percent area in season" columns show the area coverage of the growing season for each state at the corresponding dates depicted by the satellite data. The boldface figures reflect the highest percentage and area in drought in the season.

\begin{tabular}{|c|c|c|c|c|c|c|c|c|c|c|c|c|}
\hline \multirow[b]{3}{*}{ Dates } & \multicolumn{4}{|c|}{ Texas $\left(\right.$ total area $\left.=687338 \mathrm{~km}^{2}\right)$} & \multicolumn{4}{|c|}{$\begin{array}{c}\text { Oklahoma }(\text { total area }= \\
\left.180983 \mathrm{~km}^{2}\right)\end{array}$} & \multicolumn{4}{|c|}{$\begin{array}{c}\text { New Mexico }(\text { total area }= \\
\left.\quad 314927 \mathrm{~km}^{2}\right)\end{array}$} \\
\hline & \multicolumn{2}{|c|}{ Area in season } & \multicolumn{2}{|c|}{ Area in drought } & \multicolumn{2}{|c|}{ Area in season } & \multicolumn{2}{|c|}{ Area in drought } & \multicolumn{2}{|c|}{ Area in season } & \multicolumn{2}{|c|}{ Area in drought } \\
\hline & $(\%)$ & $\left(\mathrm{km}^{2}\right)$ & $(\%)$ & $\left(\mathrm{km}^{2}\right)$ & $(\%)$ & $\left(\mathrm{km}^{2}\right)$ & $(\%)$ & $\left(\mathrm{km}^{2}\right)$ & $(\%)$ & $\left(\mathrm{km}^{2}\right)$ & $(\%)$ & $\left(\mathrm{km}^{2}\right)$ \\
\hline Apr 2011 & 62.2 & 427212 & 15 & 106636 & 86 & 156727 & 27 & 49706 & 9.4 & 29580 & 0.6 & 1912 \\
\hline 23 Apr 2011 & 73.9 & 508072 & 21.3 & 146068 & 96.1 & 173929 & 29.6 & 53618 & 33.7 & 106047 & 8.6 & 27045 \\
\hline 7 May 2011 & 78.2 & 537394 & 29.1 & 200246 & 97.0 & 175491 & 28.6 & 51781 & 58.5 & 184169 & 33.1 & 104294 \\
\hline 21 May 2011 & 80.8 & 555054 & 42.1 & 289295 & 97.4 & 176306 & 40.7 & 73665 & 70.2 & 221003 & 49.2 & 155010 \\
\hline 4 Jun 2011 & 83.6 & 574760 & 52.9 & 363335 & 96.2 & 174086 & 42.2 & 76464 & 77.7 & 244753 & 60.5 & 190610 \\
\hline 18 Jun 2011 & 87.2 & 599283 & 63.9 & 439078 & 92.7 & 167814 & 41 & 75230 & 84.6 & 266339 & 71.5 & 225275 \\
\hline 2 Jul 2011 & 89.6 & 615839 & 66.1 & 454122 & 91.0 & 164657 & 45.0 & 81440 & 90.8 & 285867 & 82.8 & 260870 \\
\hline 16 Jul 2011 & 90.5 & 621962 & 73.5 & 505173 & 89.8 & 162531 & 46.5 & 84100 & 94.1 & 296374 & 90.4 & 284646 \\
\hline $30 \mathrm{Jul} 2011$ & 89.6 & 616087 & 78.4 & 539043 & 88.4 & 159985 & 56.4 & 101984 & 94.8 & 298399 & 93.1 & 293287 \\
\hline 13 Aug 2011 & 86.5 & 594450 & 76.7 & 527090 & 86.9 & 157296 & 48.7 & 88065 & 94.7 & 298093 & 94.1 & 296215 \\
\hline 27 Aug 2011 & 81.9 & 562933 & 71.6 & 492203 & 85.5 & 154788 & 47.8 & 86454 & 94.0 & 295940 & 93.7 & 295001 \\
\hline 10 Sep 2011 & 77.5 & 532446 & 69.7 & 479122 & 84.3 & 152601 & 49.8 & 90092 & 93.0 & 292745 & 92.6 & 291701 \\
\hline 24 Sep 2011 & 72.9 & 501188 & 65.4 & 449658 & 83.1 & 150419 & 47.3 & 85588 & 91.1 & 286886 & 90.7 & 285630 \\
\hline 8 Oct 2011 & 68.8 & 473050 & 60.2 & 413531 & 81.9 & 148314 & 46.2 & 83633 & 89.6 & 282163 & 89.1 & 280612 \\
\hline
\end{tabular}

report, the U.S. cattle inventory in 2011 fell to its lowest point since 1952 (USDA-FSA 2011). This report showed that roughly 200000 livestock, or $20 \%$ more cattle than in 2010, were slaughtered in Texas, Oklahoma, New Mexico, Louisiana, and Arkansas as drought forced producers to sell off their herds (USDA-FSA 2011).

\section{e. The evolution and examples of impacts of the 2011 drought using VegDRI and the DIR}

In this study, the impacts of the drought have been assessed using a "convergence of evidence" approach using the VegDRI and the DIR. In general, the 2011 drought was found to be one of the driest on record (Tables 1-3), resulting in significant impacts on several sectors of the economy across the SGP. Reports in the region disclosed that record wildfires burned uncontrollably at times and continued to threaten communities throughout 2011. In addition, dust storms occurred more frequently in the region. In Oklahoma, officials urged farmers not to plow fields in an effort to keep the topsoil from eroding and blowing away. The lack of soil moisture across much of the SGP also had significant impacts on vegetation stress as depicted on VegDRI maps. Earlier in the growing season, the SGP faced increasingly dry conditions and rising fire danger as the vegetation became unusually dry during spring 2011. These drought conditions were captured and depicted on the VegDRI maps (Figs. 4a-e). For example, the drought pattern evolved from April to October, intensifying and expanding across the panhandles of Oklahoma and Texas to southeast New Mexico.
Furthermore, the VegDRI maps showed severe to extreme drought conditions because of the exceptionally hot and dry summer. As record-breaking temperatures soared and drought intensified across the SGP (as shown by the moderate to extreme drought patterns on the VegDRI maps in Figs. 4f-j), wildfires continued to plague the SGP region during the summer. For example, the largest fire in New Mexico's history, the Las Conchas Fire, burned more than $630 \mathrm{~km}^{2}$ (about $244 \mathrm{mi}^{2}$ ) from late June to early July 2011 (National Park Service 2013). Figure 5 shows the VegDRI temporal pattern around the Las Conchas area versus climatic patterns of a nearby weather station (Albuquerque, New Mexico) using precipitation (3- and 6-month SPI) and maximum temperature data that were observed in 2011. The monthly average VegDRI shows the evolution of the vegetation stress (negative values) before the Las Conchas Fire that started on 26 June 2011 (Fig. 5). The decreasing drought pattern of the VegDRI (indicating the severe drought category) following record rainfall deficits (June rainfall was the second driest on record in $83 \mathrm{yr}$ of record keeping at the Albuquerque weather station) and high temperatures (the maximum temperature was $+4^{\circ} \mathrm{C}$ more than the monthly mean from June to August) also indicated the severity of the vegetation stress that resulted in the record-breaking Las Conchas Fire (Fig. 5).

The DIR reports showed that water flow ceased in some Texas rivers and water levels fell in numerous lakes and reservoirs as the hot sun baked the landscape. Sections of the Pecos and Rio Grande Rivers in New 


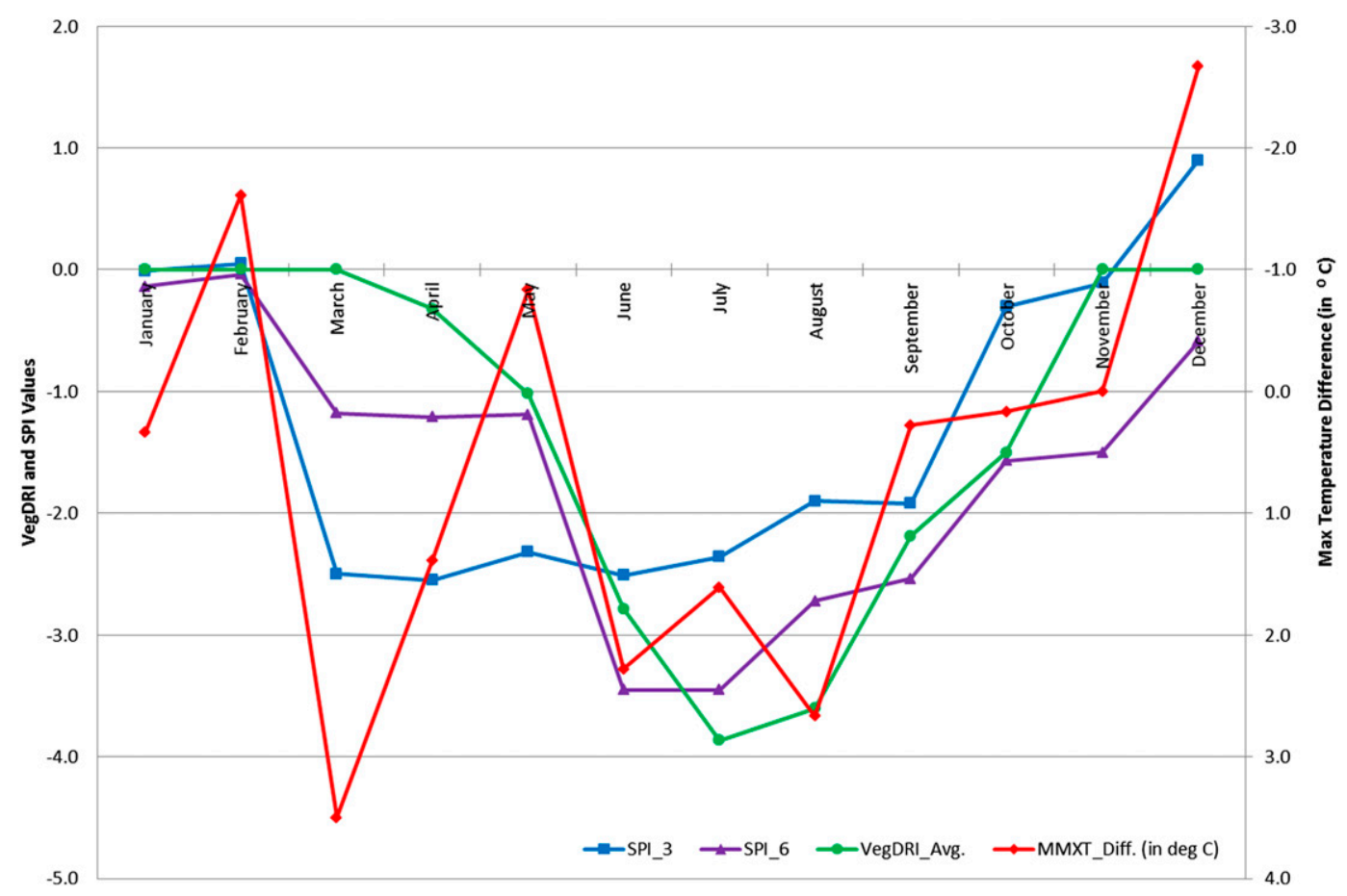

FIG. 5. The monthly average VegDRI pattern vs the climate condition around the areas of the Las Conchas Fire in 2011. The VegDRI values are extracted using $3 \times 3 \mathrm{~km}^{2}$ grids around the area of Las Conchas (i.e., Los Alamos). The 3-month SPI (SPI_3), the 6-month SPI (SPI_6), and the observed maximum temperature difference from the mean maximum temperature (MMX_Diff) are calculated using the Albuquerque weather station climate data to demonstrate the drought condition.

Mexico also went dry. Many communities throughout the region adopted water restrictions to stretch their water supplies. In addition, fire restrictions made outdoor burning illegal across nearly the entire region.

Late in the growing season, even though storms brought widespread rainfall to the region in September and October, the VegDRI maps showed that the drought's effects lingered (Figs. 4n,o) and continued to pose problems with regard to pasture recovery and reduced cattle herds-issues that take some time to be remedied in most cases. According to the DIR reports, livestock producers continued to sell cattle off in Texas while conditions deteriorated further. Livestock producers in Oklahoma and Texas strove to find feed for their cattle because forage was not growing even as some areas saw precipitation return. The cotton harvest in 2011 yielded half the amount of cotton that was produced in 2010 in parts of eastern New Mexico and western Texas. The percent area of drought in New Mexico and Texas depicted by the VegDRI in 2010 and 2011 was in agreement with these agricultural impact reports (Figs. 6a,c).

To evaluate the degree of agreement between state average VegDRI values and the drought report information from the DIR, a simple comparison and correlation analysis has been done between the percent area of the drought using VegDRI and the number of reports that are compiled in the DIR. For this comparison, the DIR reports for "agriculture" and "plants and wildlife" in Texas, Oklahoma, and New Mexico from 2007 to 2013 were used. The number of reports shows the quantity of news articles and descriptions of drought related to agriculture and to drought-affected plants and wildlife submitted by non-NDMC sources in each state. Figure 6 shows how the percent area of drought (as calculated by VegDRI) in Texas, Oklahoma, and New Mexico compares to the number of reports of drought impacts on agriculture, plants, and wildlife in the DIR for 2007-13. Generally, the results of the comparison show that the higher percentage area of drought as identified by VegDRI corresponds with the time period when the most reports were submitted for the three states. The 2011 drought year stands out from the other years (e.g., the 2010 "near normal" year). A correlation analysis has also been done for each state to evaluate the degree of agreement between VegDRI and the impacts information from the 2007-13 DIR data. For Texas, the correlation $r$ between the percent area of the state in moderate to extreme drought that is identified by VegDRI (TX_VegDRI in Fig. 6, top left) and the 

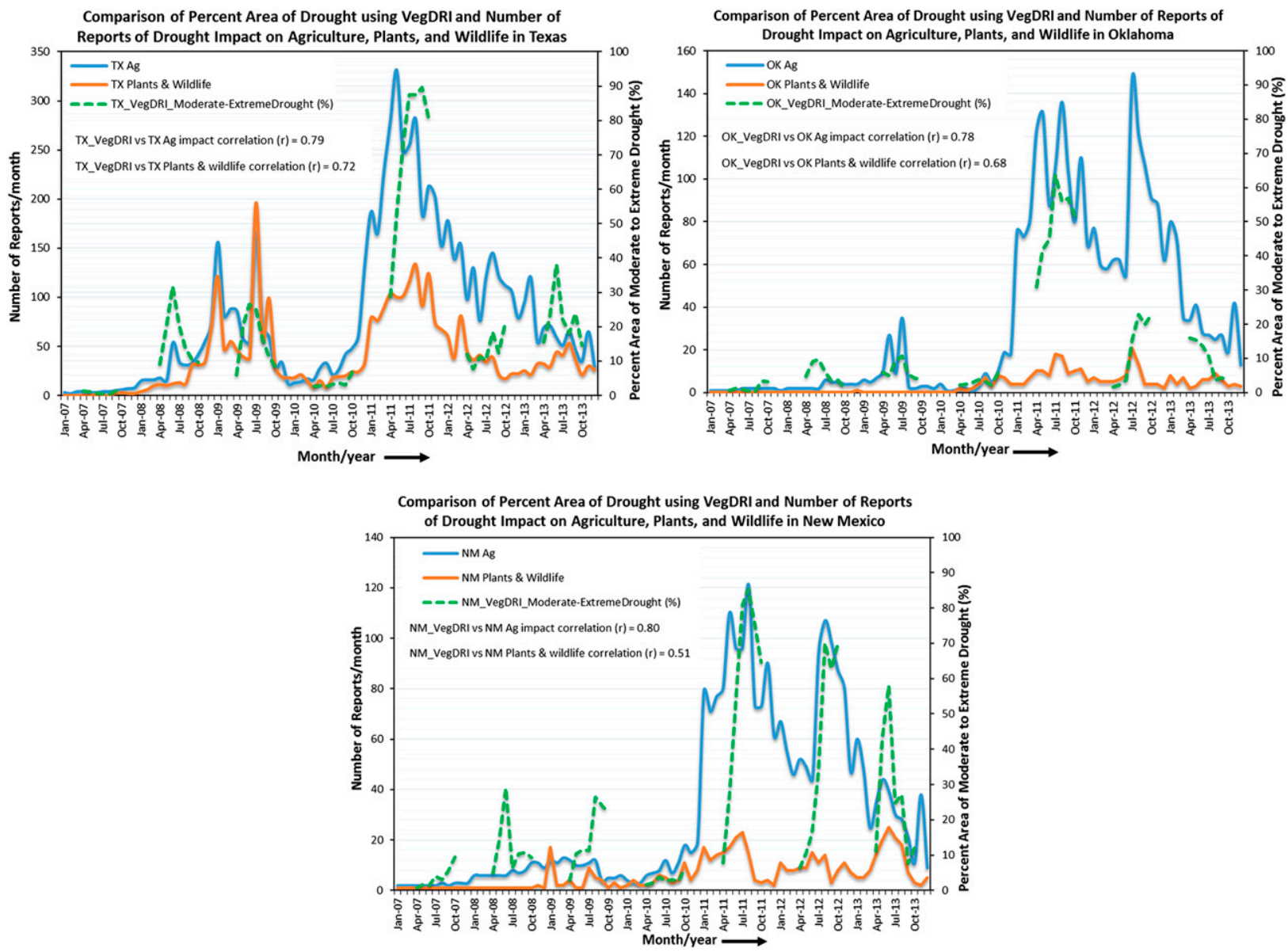

FIG. 6. Comparison of the percent area of drought in (top left) Texas, (top right) Oklahoma, and (bottom) New Mexico using VegDRI and the number of reports of drought impact on agriculture, plants, and wildlife that are compiled by the DIR from 2007 to 2013 . The VegDRI values are from April to October and the correlation values reflect only for the growing season.

number of reports about agricultural issues was 0.79 . The correlation between TX_VegDRI and the number of reports about plants and wildlife in Texas was 0.72 . For Oklahoma, the correlations between the percent area of the state in moderate to extreme drought that is identified by VegDRI (OK_VegDRI in Fig. 6, top right) and the number of reports about agricultural and plant and wildlife issues were 0.78 and 0.68 , respectively. For New Mexico, the correlation $r$ between the percent area of the state in moderate to extreme drought that is identified by VegDRI (NM_VegDRI in Fig. 6, bottom) and the number of reports about agricultural concerns was 0.80 . The correlation between NM_VegDRI and the number of reports about drought-affected plants and wildlife in New Mexico was 0.51 . Note that the number of reports often peaks during the growing season when concern over moisture stress rises and is typically lower outside the growing season. Even though the correlation between the VegDRI values and the agricultural reports is relatively high $(r>0.6)$, reporting biases (in space and time) could be influencing the number of reports within the season. Further study and improvement of the evaluation method is necessary to better understand the relationships between the drought identified by the VegDRI and drought reports about agriculture and other sectors.

\section{Future work}

Even though the VegDRI has a 1-km resolution, it could have a limited spatial precision in areas that do not have dense station networks because of its reliance on spatially interpolated climate data input. A thorough evaluation of VegDRI's accuracy (uncertainty) that is focused on the possible errors caused by climate data interpolation is planned. In addition, VegDRI will be evaluated across various land covers and topographies. The use of satellite-based precipitation estimates at $1-\mathrm{km}$ resolution (including merged satellite- and groundbased weather station data) will also be considered in improving the VegDRI models. This may help to address 
localized weather effects such as precipitation resulting from local convection and storms.

The maintenance of the existing time series of remote sensing data used in the production of VegDRI is important for the long-term success and use of satellitederived products. The development of VegDRI using other satellite sensors including MODIS is necessary and will help improve the spatial and temporal resolution of VegDRI (e.g., less than $250 \mathrm{~m}$ at a weekly interval). Currently, NDMC and USGS scientists are collaborating to produce a weekly MODIS-based VegDRI. Thorough evaluation of the MODIS-based VegDRI is planned. In addition, new sensors and missions that include the Visible Infrared Imager/Radiometer Suite (VIIRS), Landsat Data Continuity Mission (LDCM), Global Precipitation Measurement (GPM) Mission, and Soil Moisture Active Passive Mission (SMAP) may be considered as inputs for transitioning and/or maintaining data continuity as well as improving the VegDRI models and products.

Generally, the correlation between the percent area of moderate to extreme drought identified by VegDRI for the SGP and the number of impact reports on agriculture for each state ranges from 0.62 to 0.68 . The correlation between the VegDRI and the impact reports in the plants and wildlife category as compiled by the DIR ranges from 0.45 to 0.64 . However, because long and consistent historical records are not yet available for all the counties and states across the region in the DIR reports, the assessment in this study has been more qualitative at local levels. Identifying the temporal and spatial patterns of drought in a given year and assessing drought impacts in the growing season could be improved using both qualitative and quantitative data. Since the VegDRI was designed originally to assess the general vegetation condition using a combination of climate and satellite data, identifying impacts on economic sectors such as crop yields using VegDRI requires higher spatial resolution VegDRI products and investigations of VegDRIcrop yield relationships. In addition, "clip plot" data at a local level are needed to evaluate the impacts of drought on crops at field level. Thus, thorough and detailed assessments of quantified impacts at a local level (e.g., counties) and specific economic sector (e.g., crop yield) are planned in the future.

\section{Conclusions}

During the 2011 growing season, the SGP was plagued by moderate to extreme drought. Extremely hot and dry conditions persisted across the region, with numerous all-time maximum temperature records broken, worsening the impacts of drought on vegetation.
The vegetation condition assessment of the 2011 drought using VegDRI across the SGP showed significant drought impacts on several sectors of the economy as documented by the DIR. The prolonged heat and drought had drastic impacts on the region's agriculture and farming communities. For example, livestock sales hit record highs in the region as ranchers were not able to maintain their herds because of lack of forage. In Texas and Oklahoma, a majority of rangelands and pastures were classified as being in "very poor" condition for much of the 2011 growing season, resulting in total direct losses of about $\$ 12$ billion to crops, livestock, and timber (NCDC 2012). Fire restrictions made outdoor burning illegal in nearly the entire region. The largest fire in New Mexico's history (the Las Conchas Fire) occurred mainly because of the extremely hot and dry conditions. Starting in April, the temporal and spatial patterns of the VegDRI values and maps showed the evolution of the signal before the Las Conchas Fire that started at the end of June and continued in July.

Generally, the temporal and spatial patterns of the 2011 drought depicted by the VegDRI show the severity of the drought on vegetation at a subcounty, state, and regional level. This drought has significantly affected several sectors of the economy, as documented by the DIR. This kind of drought impact assessment using information from the VegDRI can be used to support management decisions including identifying locations to move livestock for grazing, assessing rangeland conditions to determine locations that may have hay surpluses or deficits, providing subcounty information on drought conditions to justify disaster assistance, fire risk assessment, and irrigation management.

Acknowledgments. This research was partially supported by NOAA's National Integrated Drought Information System (NIDIS). The authors thank Chris Poulsen, Karin Callahan, and Kelly Smith for their contributions to this work. The authors also thank Deborah Wood of the National Drought Mitigation Center for her editorial comments. In addition, the authors thank the many people who help with operational processing of VegDRI at the EROS Center, including Danny Howard, Stefanie Bohms, Terry Vaughn, Mike Steuck, and Shayam Balaji. Any use of trade, firm, or product names is for descriptive purposes only and does not imply endorsement by the authors or U.S. government.

\section{REFERENCES}

Addink, E. A., S. M. De Jong, and E. J. Pebesma, 2007: The importance of scale in object-based mapping of 
vegetation parameters with hyperspectral imagery. Photogramm. Eng. Remote Sens., 73, 905-912, doi:10.14358/ PERS.73.8.905.

Alados, C. L., J. Puigdefábregas, and J. Martínez-Fernández, 2011: Ecological and socio-economical thresholds of land and plantcommunity degradation in semi-arid Mediterranean areas of southeastern Spain. J. Arid Environ., 75, 1368-1376, doi:10.1016/j.jaridenv.2010.12.004.

Bayarjargal, Y., A. Karnieli, M. Bayasgalan, S. Khudulmur, C. Gandush, and C. J. Tucker, 2006: A comparative study of NOAA-AVHRR derived drought indices using change vector analysis. Remote Sens. Environ., 105, 9-22, doi:10.1016/ j.rse.2006.06.003.

Bhuiyan, C., R. P. Singh, and F. N. Kogan, 2006: Monitoring drought dynamics in the Aravalli region (India) using different indices based on ground and remote sensing data. Int. J. Appl. Earth Obs. Geoinf., 8, 289-302, doi:10.1016/j.jag.2006.03.002.

Blunden, J., and D. S. Arndt, 2012: State of the climate in 2011. Bull. Amer. Meteor. Soc., 93, S1-S280, doi:10.1175/ 2012BAMSStateoftheClimate.1.

Breiman, L., J. Friedman, R. Olshen, and C. Stone, 1984: Classification and Regression Trees. Chapman and Hall, $368 \mathrm{p}$.

Brown, J. F., B. D. Wardlow, T. Tadesse, M. J. Hayes, and B. C. Reed, 2008: The vegetation drought response index (VegDRI): A new integrated approach for monitoring drought stress in vegetation. GISci. Remote Sens., 45, 16-46, doi:10.2747/1548-1603.45.1.16.

Bryan, S. M., cited 2011: Combination of drought, insects hammers trees in southern New Mexico. [Available online at http:// lubbockonline.com/filed-online/2011-12-21/combinationdrought-insects-hammers-trees-southern-new-mexico\#. Uuf28PvnZpg.]

Combs, S., 2012: The impact of the 2011 drought and beyond. Texas Comptroller of Public Accounts Special Rep., Publ. 96-1704, 16 pp. [Available online at http://www.window.state.tx.us/ specialrpt/drought/pdf/96-1704-Drought.pdf.]

Gesch, D. B., K. L. Verdin, and S. K. Greenlee, 1999: New land surface digital elevation model covers the earth. Eos, Trans. Amer. Geophys. Union, 80 (6), 69-70, doi:10.1029/ 99EO00050.

Grigg, N. S., 2014: The 2011-2012 drought in the United States: New lessons from a record event. Int. J. Water Resour. Dev., 30, 189-199, doi:10.1080/07900627.2013.847710.

Hoerling, M., and Coauthors, 2013: Anatomy of an extreme event. J. Climate, 26, 2811-2832, doi:10.1175/JCLI-D-12-00270.1.

Homer, C., C. Huang, L. Yang, B. Wylie, and M. Coan, 2004: Development of a 2001 national land cover database for the United States. Photogramm. Eng. Remote Sens., 70, 829-840, doi:10.14358/PERS.70.7.829.

Jakubauskas, M. E., D. L. Peterson, J. H. Kastens, and D. R. Legates, 2002: Time series remote sensing of landscapevegetation interactions in the southern Great Plains. Photogramm. Eng. Remote Sens., 68, 1021-1030.

Karl, T. R., and Coauthors, 2012: U.S. temperature and drought: Recent anomalies and trends. Eos, Trans. Amer. Geophys. Union, 93, 473-474, doi:10.1029/2012EO470001.

Kogan, F. N., 1990: Remote sensing of weather impacts on vegetation in non-homogeneous areas. Int. J. Remote Sens., 11, 1405-1419, doi:10.1080/01431169008955102.

Maselli, F., S. Romanelli, L. Bottaib, and G. Zipolia, 2003: Use of NOAA-AVHRR NDVI images for the estimation of dynamic fire risk in Mediterranean areas. Remote Sens. Environ., 86, 187-197, doi:10.1016/S0034-4257(03)00099-3.
McKee, T. B., N. J. Doesken, and J. Kleist, 1993: The relationship of drought frequency and duration to time scales. Preprints, Eighth Conf. on Applied Climatology, Anaheim, CA, Amer. Meteor. Soc., 179-186.

National Park Service, cited 2013: The Las Conchas Fire. [Available online at http://www.nps.gov/band/naturescience/ lasconchas.htm.]

NCDC, 2012: Billion dollar U.S. weather/climate disasters 19802012. National Climatic Data Center, Asheville, NC, Tech. Rep., 7 pp. [Available online at http://www.ncdc.noaa.gov/ billions/events.pdf.]

- cited 2013: Climate monitoring: Temperature, precipitation, and drought. [Available online at http://www.ncdc.noaa.gov/ temp-and-precip/.]

NWS, cited 2011a: New Mexico monthly summaries. National Weather Service Weather Forecast Office, Albuquerque, NM. [Available online at http://www.srh.noaa.gov/abq/?n= monthly-summaries.]

_ , cited 2011b: 2011 mid-summer climate summary. National Weather Service Weather Forecast Office, Lubbock, TX. [Available online at http://www.srh.noaa.gov/lub/?n= 2011mid-summerclimatesummary.]

_ - cited 2011c: The year in weather: 2011: Oklahoma and western north Texas. National Weather Service Weather Forecast Office, Norman, OK. [Available online at http:// www.srh.noaa.gov/oun/?n=events-2011summary.]

Omernik, J. M., 1987: Ecoregions of the conterminous United States. Ann. Assoc. Amer. Geogr., 77, 118-125, doi:10.1111/ j.1467-8306.1987.tb00149.x.

Palmer, W. C., 1965: Meteorological drought. U.S. Department of Commerce Weather Bureau Research Paper 45, 58 pp.

Pervez, M. S., and J. F. Brown, 2010: Mapping irrigated lands at 250-m scale by merging MODIS data and national agricultural statistics. Remote Sens., 2, 2388-2412, doi:10.3390/rs2102388.

Quiring, S. M., and G. Srinivasan, 2010: Evaluating the utility of the vegetation condition index (VCI) for monitoring meteorological drought in Texas. Agric. For. Meteor., 150, 330-339, doi:10.1016/j.agrformet.2009.11.015.

Rulequest, cited 2013: An overview of Cubist. [Available online at http://www.rulequest.com/cubist-win.html.]

Singh, R. P., S. Roy, and F. Kogan, 2003: Vegetation and temperature condition indices from NOAA AVHRR data for drought monitoring over India. Int. J. Remote Sens., 24, 43934402, doi:10.1080/0143116031000084323.

Tadesse, T., B. D. Wardlow, M. J. Hayes, M. D. Svoboda, and J. F Brown, 2010: The Vegetation Condition Outlook (VegOut): A new method for predicting vegetation seasonal greenness. GISci. Remote Sens., 47, 25-52, doi:10.2747/1548-1603.47.1.25.

$\_, \ldots$, M. Svoboda, and M. J. Hayes, 2012: The Vegetation Outlook (VegOut): Predicting remote sensing-based seasonal greenness. Remote Sensing and Drought: Innovative Approaches to Monitoring, B. D. Wardlow, M. C. Anderson, and J. Verdin, Eds., CRC Press, 75-94.

Texas A\&M AgriLife, cited 2012: Updated 2011 Texas agricultural drought losses total $\$ 7.62$ billion. [Available online at http:// today.agrilife.org/2012/03/21/updated-2011-texas-agriculturaldrought-losses-total-7-62-billion/.]

TreeGeek, cited 2012: The 2011-2012 drought. [Available online at http://www.thetreegeek.com/news/2011-2012-drought/.]

Tucker, C. J., C. L. Vanpraet, M. J. Sharman, and G. Van Ittersum, 1985: Satellite remote sensing of total herbaceous biomass production in the Senegalese Sahel: 1980-1984. Remote Sens. Environ., 17, 233-249, doi:10.1016/0034-4257(85)90097-5. 
Unganai, L. S., and F. N. Kogan, 1998: Drought monitoring and corn yield estimation in southern Africa from AVHRR data. Remote Sens. Environ., 63, 219-232, doi:10.1016/ S0034-4257(97)00132-6.

USDA-ERS, cited 2013: U.S. drought 2012: Farm and food impacts. [Available online at http://www.ers.usda.gov/ topics/in-the-news/us-drought-2012-farm-and-food-impacts. aspx\#crop.]

USDA-FSA, 2011: Livestock Forage Disaster Program (LFP) fact sheet. USDA Farm Service Agency, 4 pp. [Available online at http://www.fsa.usda.gov/Internet/FSA_File/lfp_2011_pfs.pdf.]

USDA-NRCS, cited 2013: Web Soil Survey. [Available online at http://websoilsurvey.nrcs.usda.gov/.]
Wardlow, B. D., T. Tadesse, J. F. Brown, K. Callahan, S. Swain, and E. Hunt, 2012: The vegetation drought response index (VegDRI): An integration of satellite, bioclimate, and biophysical data. Remote Sensing and Drought: Innovative Approaches to Monitoring, B. D. Wardlow, M. C. Anderson, and J. Verdin, Eds., CRC Press, 51-74.

Wells, N., S. Goddard, and M. J. Hayes, 2004: A self-calibrating Palmer drought severity index. J. Climate, 17, 2335-2351, doi:10.1175/1520-0442(2004)017<2335:ASPDSI>2.0.CO;2.

Yang, L., C. Huang, C. Homer, B. Wylie, and M. Coan, 2003: An approach for mapping large-area impervious surfaces: Synergistic use of Landsat-7 ETM+ and high spatial resolution imagery. Can. J. Remote Sens., 29, 230-240, doi:10.5589/m02-098. 